\title{
Role of Educational Institutions in Islamization, Social Reformation and National Integration in Pakistān
}

\author{
Fidā-Ur-Rahmān \\ Lecturer, Department of Social Sciences, University College of Zhob, \\ BUITEMS. Pākistān E-mail: fidamwt@gmail.com \\ Hashmat Ullāh Khān \\ M.Phil, Department of Political Science, Hazära University, \\ Mansehra. KPK, Pākistān
}

\section{Abstract:}

Education is the key to a living and dynamic human civilization based on human creativity and productivity. Uniformity in curriculum provides a well-defined and unambiguous goal and it leads toward national integration and social cohesion. Consequently, the potential and competence of the individuals are utilized in a desired and productive manner without a slightest deviation from the defined goal. Pakistān inherited two diverse educational approaches with its inception known as Aliga'rh and Deobānd approaches, commonly known as school and Madrassā educational systems. The aim and objective of both the approaches were to educate and groom the Muslims of the sub-continent in religious and modern scientific education and to preserve the rich values and traditions of Muslim civilization from the onslaught of colonial powers. Undoubtedly, both approaches followed their initial philosophies with zeal and zest. Unfortunately, with the passage of time both the approaches have been deviating from the aims and objectives due to certain unavoidable political, social and economic factors. One is blindly following the footsteps of Western philosophy of education mainly based on materialism and the other has closed its eyes from the growing religious challenges posed by various dynamics and entirely engaged in provision of sect-based education. Consequently, the outcomes are intellectual stagnation, moral degradation, no sense of responsibility and detachment from values and traditions of Muslim civilization. A grievous gap has been widening between the followers of both approaches rapidly that causes national disintegration as well as social disorder and instability. Moreover, Muslim civilization has stopped growing and inspiring others. An attempt has been made in this paper to study and analyze both the educational approaches critically and objectively and to explore a feasible and productive way out and to fill the gap.

Keywords: Pakistān, Educational Reformation, Deformation, Islām 


\section{Introduction:}

Education has been a source of human grooming, generating human resources, gaining advancement in science and technology and dominating world cultures since the inception of human consciousness and awareness. Education may be a guarantee of gaining all the above-mentioned benefits if it has dynamism, creativity and innovation. Without dynamism, creativity and innovative approaches no nation can survive in a dignified and peaceful manner, because it gives birth to a rapidly growing, widely dominating and universally accepting culture and civilization. It is an effective way of enforcing and implementing one's thought and philosophy regarding various matters. It makes it more effective and productive in case it ingrains objectivity and universality. Education is not only a mean of physical, psychological, economic and social development and prosperity but, a path towards spiritual awakening, development of human personality and purifying inner-self of human beings. Initially, almost all the colonial powers subjugated the territories by means of latest technological advancement, up-todate knowledge and military strength, but never won the hearts of those they subdued. Later on, they tried to influence people and get their favor my introducing and implementing their own systems of education that could best achieve their vast interest. The same was experimented in the Indo-Pak Sub-continent, but the moderate scholars as well as traditional and orthodox religious clergymen reacted in such a way that resulted in establishment of two diverse educational systems ${ }^{1}$.

Before venturing into studying the core issue, it is essential to define 'Education' for getting an in-depth understanding and idea of the entire scenario and its importance in contemporary times. In fact 'Education' has been defined by various educationists, thinker, philosophers and social scientists in accordance with their own vision, understanding and idea about the process of teaching and learning.

\section{Definition of Education:}

Education is defined as the process of facilitating learning, or the acquisition of knowledge, skills, values, beliefs, and habits ${ }^{2}$, a process of cultivating human nature, habit and reason ${ }^{3}$, opening and disposing of human minds ${ }^{4}$. Merriam Webster Dictionary defines 
'Education' as the action or process of educating or being educated and the knowledge and development, skills and expertise resulting from the process. ${ }^{5}$

\section{Aligarh Educational Movement:}

Aligarh Educational Movement was started by renowned scholar, Sir Syed Ahmed Khān $(1817-1898)^{6}$. The aim of the movement was to promote modern sciences and English language in the subcontinent so that the Muslims can progress and gain their due share in the autonomy of the state based on self-respect, identity and dignity.

Aligarh educational movement succeeded in its movement to some extent especially with reference to material wellbeing and economic prosperity but, it was considered as a threat to the cultural values and religious doctrine of Islām by the traditional scholars like the founders of Deoband educational movement and his opinions and thoughts regarding various religious issues and challenges of that time were declared as 'against Islām' and doctrinal codes established by the pious Imams and their immediate predecessors ${ }^{7}$. Despite the opposition and disagreement of the staunch opponents of the Aligarh educational movement, it is known fact that it groomed and produced a lot of intelligent, visionary and charismatic academicians, intellectuals, thinkers and politicians whose imprints can be found in almost all walks of life in that time.

\section{Deobānd Educational Movement:}

It was basically a religious seminary, located at Deobānd, a town of district Saharanpur in Utter Pradesh in India. It was established by Maulānā Muhammad Qāsim Nanotvi ${ }^{89}$. It was a reaction to the educational policy of the British Empire. Moreover it was conceived that Sir Syed Ahmed Khan was promoting the same agenda of colonial rulers in another way by founding own educational institute with sole aim of Westernized educational system and promoting curriculum that was mostly based on English literature, modern sciences and technology. ${ }^{10}$ While on the other hand, the entire focus was on religious education in Darul Uloom Deobānd. The main curriculum was Dars-e-Nizami ${ }^{11}$ that includes Quranic sciences, Hadith sciences, jurisprudence, philosophy, Islāmic history, Arabic grammar etc. that is still being taught after incorporating few minor changes. They follow Hanafi principles of jurisprudence. 
The system of education is prominently called as Madrassa, which is a place of education; both secular and religious ${ }^{12}$ but, the term 'Madrassa' is generally used for the religious seminaries or schools in the sub-continent.

It is believed that Pakistan inherited very few religious seminaries, or Madrassas, after its inception but, later on Madrassas were rapidly established after the invasion of USSR on Afghanistan and US-led alliance against USSR sponsored and favored the widespread chain of religious seminaries with the help of Saudi Arabia. ${ }^{13}$ The US and its allies including Saudi Arabia used Madrassas as nurseries for breeding mercenaries in disguise of 'Jehad' and brainwashed them to fight a 'holy war' as a 'freedom fighter' against the USSR. It makes sense that keeping in view the conduct of Madrassas in past, US and its alliance label Madrassas as a breeding places for religious extremists in order to fight proxy war against USSR.

Madrassa system of education has a very rich and profound past containing modernity and diversity in curriculum and instructions. It is believed that Mujaddid Alf-i-Sāni, declared as a 'religious genius' by Allamā Iqbāl, Nawāb Sā'ad Ullah Khān who was Prime Minister of the then Mughal Empire and the great architect of the famous piece of creative architecture and one of the world famous tourist place, Täj Mahal, had all the graduates from the same education system ${ }^{14}$. It shows that education system of the Madrassas of that period was not confined to religious education. There was an atmosphere that could enable each and every individual to explore and exploit his potential by fostering diversity and modernity in the curriculum.

There are five sub-systems within the Madrassa education system established independent and separate boards of different schools of thought like Deobānd Barelvī, Ahle Hadees, Jamät-iIslāmī and Shiā ${ }^{15}$. Wafāq ul Madāris Al Arābia represents Deobāndīs, Tanzīm ul Madaris represents Barelvīs, Wafāq Ul Madaris Al Shī̄ represents Shiā Rābitatul Madāris Al Islāmiya represents Jamāt-i-Islamī and Wafāq ul Madāris Saläiya represents Ahle Hadīs.

\section{Objectives of Education:}

Although 'Education' is defined differently by different scholars, but the common point in all their thoughts and ideas is that 
all of them strived to bring positive and productive change in behavior and conduct of a human being by discovering his potential, grooming his learning skills and expanding his capability of creativity and innovation.

Pakistan inherited two diverse educational philosophies and systems immediately after its inception. One is called school or in other words secular education established by Sir Syed Ahmed Khan and the other is called Madrassa education system, or in other words religious education founded by Maulānā Qāsim Nānotawi. It was conceived that the educational policy of the colonial powers was not in compliance with the cultural values and traditions of the Muslims of the subcontinent and the policy was thought to be an attempt to detach Muslims from their religion, Islam. ${ }^{16}$ The British Empire paid more attention to gaining their financial interests than the wellbeing and development of the masses of the subcontinent. But, later on, they started introducing and implementing their educational policy. The aim of their educational policy was not educating the people but controlling their minds for their own interest and intentions of expanding and strengthening the frontiers of their dominance ${ }^{17}$. Consequently, English language was introduced as a compulsory medium of instruction by replacing Persian. Although both the systems were established to awaken and reform the Muslims of the then Indo-Pak and pull them out from the pitch darkness of ignorance and decline without compromising on their religious ideals, cultural traditions, and rich civilization, but their philosophies, understanding of the issue, pattern of action and method of education were different. Madrassa education system is one of the largest educational systems that provide free education as well as fulfill other needs of the students like food, books etc. Currently, Pakistan has six different systems of education, which are further divided ${ }^{18}$. A concise introduction will be better for a background understanding of both the educational systems.

In every society education, educational institutions and curriculum are deemed to be doing the function of reformation in society not deformation. But here in Pakistan it is leading toward wide range deformation. Its deformation phenomena is not only found in religious education but the secular/modern education is also hanging behind this issue. Education shapes moral character as well as creating such a personality to compete and work for the 
betterment of society and leads to the progress and development of the society. In Pakistan today educational institutions are not playing this role. The students of religious institutions are turning to anti-state elements. They have serious complaints in their minds against governmental machinery and middle and upper middle classes of Pakistan.

On the other hand, the modern education or western model educational institutions of Pakistan are also leading toward deformation. They have not been able to fulfill their due role of reformation so far. These institutions have created a wide range of class distinction among the respected citizens of Pakistan. They have created elite class, upper middle class, middle class and lower middle class in Pakistan. This thing further deteriorated the principle objective of the creation of Pakistan in 1947. The students of colleges and universities are involved in unacceptable activities, drug addictions, moral degradation, wasting of their precious time and hardly earned resources of their parents. When they get degrees and have a job in any institution then they do not work sincerely and committedly. They became lazy, do corruption, nepotism and favoritism.

\section{Implications of educational deformation:}

There are many issues and shortcomings in the existing systems of education - both religious and secular. It is believed that these shortcomings caused deformation in Pakistan instead of reformation. On completion of education they carry their sick minds to work places and show least commitment with sincerity and indulge themselves in all sort of illegal activities such as embezzlement, nepotism etc thus harming the interests of the society.

1. Disunity: Pakistan has been facing the dilemma of disunity among followers of various educational traditions for decades. The issue became graver due to interference and involvement of various national and international factors like religious sectarianism, Afghan war, Zia's Islamization of state and society and frequent discontinuity in democratic political process etc. No doubt, Pakistanis are divided into various nationalist, linguistic and sectarian groups, but the most monstrous of these is religious sectarianism resulting from religious extremism, which has shattered to pieces the 
peaceful and productive social fabric and compassionate social traditions of Pakistani society irrespective of any specific region. Moreover, Pakistani society is divided into Mulla and Mister, which is a deadly blow to the national integration. Followers of both educational systems, without few exceptions, are not ready to sit together, listen to each other, discuss reservations and settle the misconceived differences through dialogue in an academic way instead of following preconceived and mostly baseless concepts about each other. Pakistan has been striving hard for generating a sense of collectivity based on a single ideology and identity. But unfortunately it is some like a crowd that gather for certain temporary reasons like carrying a coffin or recovering dead bodies from debris.

There is a disturbing variety of educational systems in Pakistan like public sector, private sector and religious seminaries. Further divisions and varieties of educational institutions as per the requirements and status of different social classes can also be observed within the abovementioned educational systems having different types of curriculum and instructions, some of them have even been teaching foreign curriculum and instructions that do not suit the local cultural values and traditions. In fact Allah, the Almighty, strictly discourages sectarianism and divisions and encourages to hold the rope of Allah (The Noble Qur'an) and do not be divided because unity and fraternity is a blessing of Allah, the Almighty ${ }^{19}$. There are five separate boards of religious seminaries that depict the fact that division is not limited to secular educational institutions but, religious seminaries are also contributing to the grievous and widespread division on the basis of beliefs. Unfortunately, it has been accepted as an unavoidable truth at the governmental and state level and nothing is being done to eradicate these evils ${ }^{20}$.

The large number of students' unions and bodies with different flags, slogans and mottos further testify to the bitter truth. Students are unable to realize the importance of gathering under a single flag with a collective slogan and 
motto of wellbeing and welfare of the entire nation instead of serving agendas of certain parties.

Most importantly, Islam encourages mutual harmony and unity among believers and further elaborates that believers are brethren among themselves ${ }^{21}$.

2. Lack of Sense of Life Goal: Unfortunately, our students as well as teachers are unaware of the importance, value and actual objectives of the education. They are engaged in a process, which culminates in just getting a degree and obtaining a job. There is only a handful of students who are engaged in getting education with the aim of getting inspiration, knowledge, wisdom and insight to be utilized for their own betterment as well as in the wide interest of the nation or country. Moreover, due to lack of objectivity in students end, materialistic tendency and selfish trends are growing very rapidly. Their interest, efforts and potential are utilized for self-aggrandizement instead of collective welfare. The same issue can be observed in religious seminaries in a different form. Religious seminaries are established by various schools of thought where they teach their own syllabus with their own approaches and techniques. There are approximately 40,000 religious seminaries in Pakistan ${ }^{22}$ and the number is still booming with the passage of time. They have independent and separate examination boards and the entire process revolves round the promotion of a certain school of thought instead of the preaching and teaching of Islam while meeting its universal role. Consequently, the division further aggravates and poses a threat to national unity and cohesion.

3. Creativity \& Innovation: Unfortunately, there are very few educational institutions that pay attention to the promotion and development of students' critical and analytical skills. Sciences are supposed to be taught for creating critical and analytical reasoning as well as qualitative and quantitative analysis among the students but unscientific and nonacademic approaches and understanding of the university's graduates can be observed.

On the other hand, students of religious seminaries focus on memorizing the subjects instead of developing their 
skills of analysis that leads to mental stagnation ${ }^{23}$. The

main focus is on the research and interpretation of the scholars who worked on different fields and areas of Islam as per their training, understanding, social needs etc. It is mostly discouraged to opine against or different than the religious understanding and interpretation of the previous scholars. It is generally believed that the research done and jurisprudential principles established and applied by those scholars are sufficient to cope with the issues of every age.

Madrassa education system as a whole has no set rules regarding admission as compared to school education system. Although some of the Madrassas have been conducting admission tests and they have a certain criteria for admissions as well yet majority of the Madrassas have no standard procedure for admission. Little attention is paid to the fact that every individual has a different aptitude and potential and it is unjust to admit a child in a Madrassa in an early age and educate him about religious teachings without taking care of his potential and natural aptitude. It is believed that a child must not be admitted to a Madrassa before getting twelve years basic education ${ }^{24}$ keeping in view his natural aptitude and development of necessary skills.

Another issue is that most of the graduates of modern educational system do not know the basic facts about fundamental doctrines of Islam. At the same time, students of religious seminaries do not have any better or in-depth understanding of the modern challenges posed to them due to rapidly growing globalization. Although few religious seminaries $^{25}$ have been striving to achieve this goal by arranging seminars, training sessions and conferences but, still much needs to be done in this regard by adopting same in all others religious seminaries.

4. Moral Degradation: Educational institutions are meant to bring positive and productive changes in the behavior and conduct of a human being by grooming and strengthening their moral side. Unfortunately, the situation seems worse in the urbanized societies compared to rural societies as long as the acceptable behavior is concerned. As a result rural societies are more conscious about the sanctity and 
promotion of moral values than urban societies, where even the close neighbors do not have any knowledge about others next door. Above all recent cases of corruption prove the bitter reality as most of the educated people are involved in monetary and moral corruption. Religious seminaries are based on sectarian basis. Consequently, they promote their own ideologies on the basis of negating or even degrading the religious interpretations and understandings of other sects and schools of thought. ${ }^{26}$ It gives birth to non-academic, irresponsible and hatred-based religiosity, whose entire focus is to promote their own sect and school of thought by hook or by crook.

5. Dominance of Western Culture: Youth has been rapidly westernizing in their physical outlook as well as their way of thinking, observing and understanding various phenomena. Western civilization has been dominating due their hold and huge investment on print, electronic and social media. Media in Pakistan has been following the footsteps of Western civilization blindly while compromising the rich cultural values and traditions of the region. Western culture is dominating Pakistani society because our civil society is not interested in promoting regional culture and civilization rather it promotes Western cultural values without estimating their negative impacts.

Instead of adopting and promoting Islamic values and culture, the youth is blindly following, Western cultural values and traditions like Father's and Mother's Day, Valentine's Day, April Fool etc. Unfortunately, they are unaware of these western traditions and practices which might have damaging effects on their own values.

6. Drug Addiction: the culture of drug consumption in the university and College students irrespective of their gender is booming fast. Allah Almighty has declared intoxication as an act of abomination devised by $\operatorname{Satan}^{27}$. Recently a student of LUMS University was found dead due to overdose of drugs. ${ }^{28}$ At the same time, it was also highlighted in media circles that consumption of ICE-Drug is rapidly growing in Peshawar-based educational institutions of higher education. ${ }^{29}$ Shishā is considered as a normal and routine 
fashion of the day. It was discovered in a high level meeting of Senate Standing Committee on Interior and Narcotics Control that in Islamabad alone 53\% students of private schools were consuming either artificial or hard drugs or addicted to heroin and, surprisingly, their age groups were categorized as $12-16$ and $16-19$. It was also an astonishing revelation that the intoxicants were provided by the fellow students or teachers. ${ }^{30}$

\section{Recommendations:}

1. Educational Institutions must be free from every kind of political involvement and influence. Students' must not be allowed to join hands with any political parties during their academic tenure in the educational institutions.

2. Special and preferential attention needs to be paid to the overall moral training, character building and spiritual awakening of the students instead of preparing them for the merciless and selfish race and competition of earning more and more pennies.

3. Uniform curriculum should be taught in all educational institutions of the country and the division of private and public, English and Urdu medium must also be banned so that the dream of national integration, unity and fraternity comes true.

4. Sect-based establishment of religious seminaries should be discouraged and banned. There must be a uniform curriculum of religious education as implemented in other Muslim countries.

5. Teachers of all levels should emphasize the need and importance of knowledge and wisdom instead of memorizing facts and figures and awarding degrees without having an in-depth knowledge and insight.

6. Islamic Cultural values and traditions should be promoted in educational institutions. Furthermore, Madrassas should also make arrangements for the introduction and promotion of modern social sciences for getting insightful knowledge and understanding of the modern social, economic and political thoughts and philosophies.

7. Arabic and Persian should be taught as compulsory subjects at college and university level so that students 
can be familiarized with the rich literature already available in Arabic and Persian. At the same time English language should be taught in Madrassas because, it is not just a language, but a way of communicating with the global culture and civilization. Moreover, the cultural and academic onslaught of globalization can only be countered if one is capable of understanding the diction and style of communication of the modern age.

8. Research institutions and research culture should be established and promoted. Orientalism has been a very powerful and decisive means of propagating ideas against and in favour of Islam. It is necessary to establish such research institutions that can respond to the reservations, objections and challenges of the Orientalism in academic way.

9. Centers of Excellence in Islamic Banking (CEIF) have been established in various institutions of higher education in Pakistan but, most of the high-ups and teaching faculty in the centers are foreign qualified. It is required that such centers should also be established in religious seminaries in the same pattern to provide more authentic, sophisticated and relevant advice to the trainees.

10. Joint training sessions, seminars and conferences should be arranged for the teachers and students of both modern educational institutions and religious seminaries to bridge the gap between them and offered an opportunity to share their thoughts and knowledge with each other and other opinions therewith.

\section{Conclusion:}

Students are the asset and future of Pakistan. They are duty bound to work for the betterment of society. An analysis of the performance shows that both system of education failed to reform the society or bring about any change for the better. Religious institutions have led to religious extremism, and modern institutions create class consciousness, materialism, drug culture and moral degradation among students. To solve all these issues it is needed to revise the whole curriculum, revisit the existing teaching methodologies and focus on the character-building of students and 
teachers for a productive and positive performance. It is also needed to integrate both the systems into one whole and get rid of the discriminatory approaches.

\section{Notes \& References:}

1 M.M.S Mian, Ulema-e-Hind Ka Shandar Maazi, (Maktaba shidiya Karachi, 1992), p. 42-43.

2. Dewey John, Democracy and Education, (The Free Press, 1944). pp. 14.

3. James W. Encyclopedia of Education, 2nd edition, (2002). New York, NY: Macmillan.

4. Locke, John, Locke's Conduct of the understanding, (Oxford: Clarendon Press, 1764).p. 44.

5. https://www.merriam-webster.com/dictionary/education (Accessed on 15.01.2017).

6. Syed Ahmad, also known as Sir Syed, was a Muslim reformist in the nineteenth century while the colonial powers subjugated the People of the Indo-Pak Sub-Continent.

He studied the Quran and sciences and pursued legal studies at the University of Edinburgh later on. Sir Syed joined the service of East India Company in 1838 as a judge and retired in 1876 . He remained loyal to the British Empire and saved a lot of the European people during the historical clash between British empire and Muslims of the Indo-Pak Sub-continent commonly known as War of Independence and also remembered as the great revolt of 1857. After the War od Independence/Revolt, he wrote his famous booklet, known as The Causes of the Indian Mutinyactually a critic of the conduct of Muslims regarding War of 
Independence/Revolt as well as of British policies. Sir Syed believed that Muslims of the Indo-Pak Sub-continent can be pulled out of the pitch darkness of decline and decadence by educating them on modern scientific lines. Whatever he established in the shape of schools and colleges were all the manifestation of his concept of Muslim reformation through updated and standard education.

M.M.S Mian, Ulema-e-Hind Ka Shandar Maazi, (Maktaba Rashidiya Karachi, 1992), Vol. 5 p. 42-43

8. Maulānā Muhammad Qasim Nanotvi (1833 - 1880) was an Islamic Scholar and the main person responsible for establishing Deobānd Movement. He was born in a Siddiqui family in 1833 in Nanota, a village near Saharanpur, India.

9. Tayyeb, Q. M., Maslak 'Ulama-e-Deobānd, (Karachi: Dar ul Isha'at, 2005).

10. M.M.S Mian, Ulema-e-Hind Ka Shandar Maazi, (Maktaba Rashidiya Karachi, 1992), p. 42-43.

11. Zaman, Muhammad Qasim, Religious Education and the Rhetoric of

Reform: The Madrasa in British India and Pakistan". Comparative Studies in Society and History, 41 (2) (January 2014), p. 294-323.

12. Christopher M. Blanchard, "Islamic Religious Schools, Madrasas: Background" (DTIC Document,2007), http://oai .dtic.mil /oai/oai ?verb $=$ ge tRecord \&metadataPrefix $=$ html\&identifier $=$ ADA463792 (Accessed on 15.01.2017).

13. Iqbal, A.R. et all (2015), Madrassa Reforms in Pakistan: A 
Historical Analysis. IISRA Papers, p28

14. Ghazi, M.A (2009) Musalmano Ka Deeni-o-Asri Nizam-e-

Taleem, Al Sharia Academy, Gujranwala, p19

15. Sultan Ali, Madrassa Reform and State Power (Islamabad: FNF, 2012).

16. Ramzan, Ainee, et al., Darul Uloom Deobānd -Its Evolution in the 19th Century British India and Impact on the System of Education in Pakistan, FWU Journal of Social Sciences, Winter 2013, Vol. 7, No. 2, p. 157.

17. Evans, S., 'Macaulay's minute revisited: Colonial language policy in nineteenth-century India', Journal of Multilingual and Multicultural Development, Volume 23 (4), (2002), p. 260-281.

18. IPS (2005). Pakistan Main Yaksan Nizam-e-Taleem (in Urdu), Islamabad: Institute of Policy Studies.

19. Al Qur'an 03:103

20. Rehman, T., The Madrassa and the State of Pakistan Religion, poverty and the Potential for violence in Pakistan, (Islamabad: Policy Research Institute, 2004).

21. Al Qur'an 49:10

22. Iqbal, A.R., et al., (2015), Madrassa Reforms in Pakistan: A Historical Analysis. IISRA, P. 29.

23. Tariq Rehman, Denizens of Alien Worlds: A Study of Education, Inequality and Polarization in Pakistan, vol. 17, (Oxford: Oxford University Press, 2005).

24. Saleem, Shehzad, Selected Essays of Javed Ahmed Ghamidi, (Lahore: AL Mawrid, 2015), p. 81.

25. Like Al Sharia Academy Gujranwala www.alsharia.org

26. Ibid 


\section{Al Qur'an 05:90}

28. http://www.pakistantoday.com.pk/2016/12/14/lums-student-died-of-drugoverdose-post-mortem-report/ (Accessed on 15.01.2017).

29. Peshawar ICE Case

30 . The News, October $20^{\text {th }}, 2016$

@ 2017 by the author, Licensee University of Chitral, Journal of Religious Studies. This article is an open access article distributed under the terms and conditions of the Creative Commons Attribution (CC BY) (http://creativecommons.org/licenses/by/4.0/). 